\title{
THE INTENSITY OF MONGOLIAN INFLUENCE IN THE TUVA LANGUAGE*
}

\author{
BAIARMA KHABTAGAEVA \\ University of Szeged, Egyetem u. 2, H-6722 Szeged, Hungary \\ e-mail: baiarma@hotmail.com
}

\begin{abstract}
Among the Turkic languages the Tuva language possesses the largest number of Mongolian loanwords. This paper tries to prove that unilateral bilinguism played the decisive role in bringing about this phenomenon. The author illustrates the intensity of the Mongolian influence by using linguistic criteria. Then two types of loanwords are presented. The loanwords of the first group were borrowed twice from Mongolian, while in the second group Mongolian loanwords were borrowed despite the fact than an original Turkic word with the same meaning had already existed.
\end{abstract}

Key words: Tuva, Mongolian loanwords, bilinguism.

Possessing the largest number of Mongolian loanwords, the Tuva language occupies a very special place among the Turkic languages. The vast number of Mongolian loanwords can be explained by various factors (geographical, historical and cultural ones), the most important of which seems to be the bilingual state of the Tuvan people. This bilinguism was unilateral, namely the Tuva-speaking people spoke Mongolian, while the Mongols did not speak the Tuva language (Vladimircov 1929, pp. 14-15; Tatarincev 1976, p. 7). This phenomenon can still be observed in the territory close to the Mongolian border, where the Tuva people are in fact mostly trilingual, since today the Republic of Tuva is part of the Russian Federation.

The influence of the written literature is not negligible either. Until 1930, the Tuva people did not have their own writing. Mongolian writing and language were used in the administration and everyday life. ${ }^{1}$ The first pieces of Tuva folk-poetry were recorded in Mongolian writing. For example, two versions of the Geser epic exist in Mongolian writing, one of which is a Mongolian version, while the other re-

* This work has been carried out in the Research Group of Turkic Linguistics of the Hungarian Academy of Sciences and the University of Szeged.

${ }^{1}$ For a description of manuscripts and xylographs of this type, see the works of Sazykin (1992) and Samdan (2000, p. 129). 
veals the features of Tuva folk-poetry (Kuular 1961, p. 195). In sum, the Tuva-Mongol contacts were very intensive, covering all aspects of the life of the Tuva people.

The presentation of this intensive Mongol influence as reflected by the Mongolian loanwords of the Tuva language has been the main goal of my PhD dissertation. Out of the approximately 1500 Mongolian loanwords in the Tuva language, about 1400 are discussed. As a result of this work, relying on linguistic criteria I have succeeded in separating an earlier and a later layer. Within the later layer, there is a possibility to make distinction between Khalkha, Buryat and Oirat loanwords.

There is a special group of loanwords of Mongolian origin in Tuva, for which I cannot ascertain when and which Mongolian language they were taken from.

Words that reflect an archaic Mongol form are considered to be "older" ones. Having entered the Tuva language generally they fully adapted the phonetic rules of the Tuva language. In contrast, loanwords form the modern layers entered the Tuva language only after certain linguistic changes had already been accomplished there.

In my paper I will present two groups of examples to illustrate the intensity of the Mongol influence. In the first group there are five words, which although with different meanings, were borrowed twice by the Tuva language from Mongolian. In the second group I will present loanwords borrowed from Mongolian despite the fact that the Tuva language had an original Turkic word with the same meaning. This group may be divided into three sub-groups. In the first group, it is noteworthy that the same Mongolian phoneme behaves differently, depending on the time of borrowing.

\section{Words borrowed twice by the Tuva language}

1. The Mongolian word čagan 'white; light (of colour); the white of an egg or of the eye' entered the Tuva language in two different forms: šag $\bar{a}$ and sagān.

a. In the case of šag ' 'ust. novogodnij prazdnik (prazdnovalsja v fevrale), ${ }^{2}$ the change of $*_{c^{-}}>\check{s}$ - is a regular phenomenon of the Tuva language, showing that the word belongs to the earlier layer. For example:

Old-Turkic čaq- 'to strike fire (with a flint and steel); (of a snake or scorpion) to bite, sting' (ED 405b) > Tuva šak- 'čirkat' (spičkoj), vysekat' kresalom ogon";

Old-Turkic čap- 'an onomatopoetic verb with several meanings both Trans. and Intrans., the only connecting link between which seems to be that they all describe noisy action' (ED 394a) > Tuva šap- 'skakat' na kone; napadat' (obyčno o žerebce i verbljude); bit', udarjat";

Old-Turkic čolpan 'the planet Venus' > Tuva šolban 'jarkaja zvezda (napr. Venera); peren. majak, peredovik proizvodstva';

b. In contrast, the change of $* \check{c}$ - to $s$ - in the word sagān 'belyj, sedoj, sivyj; belok' is peculiar to the Buriat language, placing this word in the later layer. For example:

${ }^{2} \leftarrow$ Mongolian čaran sara '[literally white month] the first month of the year, new year'. 
Tuva sam 'ust. sam (religioznyj tanec-pantomima monahov)' $\leftarrow$ Buryat sam 'ust. cam (svoeobraznaja misterija u lamaistov)', cf. Literary Mongolian čam 'Lamaist masked dance cham (incorrectly called "devils" dance)', Khalkha cam 'religioznyj tanec-pantomima monahov', Oirat čam 'the tsamdances, a rite of mediation, the 'devil dance', Kalmuk $t$ sam 'eine religiöse Feier mit Tanz und Maskerade' $\leftarrow$ Tibetan 'cham 'to dance; also a dancer': cp. khro-'cham-pa 'who dances in frantic leaps wearing a frightful mask' (Das 442a);

Tuva sek 'znak prepinanija' $\leftarrow$ Buryat seg 'zapjataja', cf. Literary Mongolian čeg 'a dot, point, period; a Mongolian punctuation mark corresponding to a comma', Khalkha ceg 'tochka', Kalmuk tseG 'Punkt, Interpunktion' Tibetan tsheg 'the point separating syllables' (Das 1031a);

Tuva seserlik 'park, skver; palisadnik' $\leftarrow$ Buryat seserlig 'cvetnik; redko klumba; sad; cvetuščij', cf. Literary Mongolian čečeglig čečerlig 'flower garden; flowering, blossoming', Khalkha cecerleg 'sad, park', Oirat čečeqliq 'garden, park, flower garden' $\leftarrow$ Turkic: Old-Turkic čečäklik 'flower garden' < čečäk 'flower' (ED 401a, 400b).

2. The second Mongolian word examined is jolig 'ransom, rescue; figurines usually made of dough which are used in Lamaistic ritual for ridding one of evil spirits causing illness; devil (curse)'. It deserves our special attentionin many respects. It entered the Tuva language in two different forms: čoluk 'sacrifice' and soyluk 'rogue'. I regard both of them as belonging in the earlier layer.

a. The Tuva word čoluk 'negodjaj, podlec; ust. rel. žertva, žertvoprinošenie' behaves in accordance with the phonetic rules of the Tuva language. The sound $\check{c}$ - is a result of phonemic replacement, because there is no sound $\check{j}$ - in the Tuva language. For example:

Tuva čayān 'sud'ba, dolja, učast', udel; sposobnost', odarennost', talant' $\leftarrow$ Mongolian: Literary Mongolian jayayan 'fate, destiny, predestination (often understood as the result of a person's good and evil deeds in previous incarnations); luck, fortune, merits accumulated in a former life' < jayaya- 'to grant, bless, ordain (by God or heaven); to predestine', Khalkha jayā(n) 'sud'ba, rok', Buryat zayá(n) 'sud’ba; ust. duhi šamanističeskogo panteona', Oirat zaya(n) zayán 'fate, lot, destiny', Kalmuk zayán 'Los, Teil, Schicksal; Prädestination';

Tuva čeme 'uprek, ukor, poricanie; prepiratel'stvo' $\leftarrow$ Mongolian: Literary Mongolian jeme ǰme 'conduct, manner of behaviour, procedure; blame, reprimand; fault', Khalkha jem 'prostupok, vina', Buryat zeme 'vina, prostupok, prerstuplenie; zamečanie, vygovor', Oirat zeme 'guilt, reproach, scolding; discipline; sacred instructions', Kalmuk zem ${ }^{\ddot{a}}$ 'Verweis, Tadel, auch: Schuld, Vergehen';

\footnotetext{
${ }^{3}$ The change of $* g>r$ before $* l$ is mentioned by Poppe in his "Comparative Studies" (1955, p. 154).
} 
Tuva čon 'narod; naselenie' $\leftarrow$ Mongolian: Literary Mongolian jon 'people', Buryat $z o(n)$ 'narod, ljudi, naselenie';

b. The phonetic form of the word soyluk 'rogue' is rather strange. I think that this form is a result of a metathesis, in the same manner as in the following examples:

Tuva boydus 'priroda' $\leftarrow$ Mongolian: Literary Mongolian bodis 'body; material substance', Khalkha bodis 'predmet, telo, materija', Buryat bodos 'veščestvo';

Tuva koynut 'ukrop' $\leftarrow$ Mongolian: Literary Mongolian yonid 'caraway, Carum buriaticum, Saposhnikovia divaricata', Khalkha gon'd $\sim$ gonid 'tmin burjatskij, anis', Kalmuk gon'iD 'ein wohlriechendes Kraut (Petrosilium?), das in die Suppe gelegt wird, Kümmel?' $\leftarrow$ Tibetan go-snyod 'cummin seed' (Das 226b);

In some cases an initial Tuva $s$ - appears in the place of a Mongolian $\check{j}$. For example:

Tuva súgu 'peč', pečka' $\leftarrow$ Mongolian: Literary Mongolian juuqa 'hearth, furnace, stove', Khalkha jūx(an) 'peč', pečka', Buryat 'jama dlja razvedenija ognja; glinobitnyj očag', Oirat juиqa zóxo zúxa(i) 'firepit', Kalmuk zúxa 'eine kleine Grube in der Erde: ein kleiner Keller; ein (auf der Reise) in der Erde gemachter Ofen' $\leftarrow$ Chinese zào huo;

Tuva sagbar 'obrazec, šablon dlja čekanki (vyrezaetsja iz bumagi)' $\leftarrow$ Mongolian: Literary Mongolian jaybur 'minta, modell; szabásminta; alak, forma' [model; pattern; form] (Kara 1998, p. 189a), Khalkha jagwar 'vykrojka, obrazec, model'; forma, vid';

Tuva sodak 'odežda borca $\mathrm{v}$ nacional'noj bor'be; trusiki' $\leftarrow$ Mongolian: Literary Mongolian jodo $\sim$ joday 'a tight jacket worn by Mongolian wrestlers' < jodo- 'to beat, hit', Khalkha jodog 'special'naja odežda borcov, sostojaščaja iz rukavov i uzkoj spinki', Oirat dzodag;

The presence of initial $s$ - in the Tuva equivalents of the Old-Turkic words yultuz 'star' and yastuq 'pillow' belong to the unsolved problems of Turcology ${ }^{4}$. The Mongolian loanwords bring us closer to a solution because they show that the Tuva words may be loanwords from a certain Turkic language which preserved the initial $\check{y}$-: Old-Turkic $* y->*^{-}$- $>$Tuva $s^{5}{ }^{5}$ :

Old-Turkic yultuz 'star' (ED 922b) > Tuva sïldis 'zvezda';

Old-Turkic yastuq 'something propped up; pillow' (ED 974a) > Tuva sïstik 'poduška; podstavka, upor';

3. The next example comprises a base-verb and one of its Mongolian derivatives.

a. Tuva čada- 'ne moč', ne byt' v sostojanii, ne udavat'sja' $\leftarrow$ Mongolian yada'to have no strength or power; to exhaust; to be in need; to suffer; to be unable'.

The Tuva initial $c$-, reflecting the Mongolian $y$-is a regular phenomenon in the earlier layer. For example:

Old-Turkic yïl 'year' (ED 917a) > Tuva čil 'god, leta';

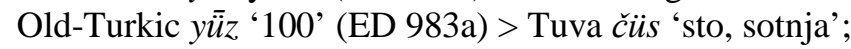

${ }^{4}$ The regular phenomenon in Tuva is the change of Old-Turkic $*_{y-}>*_{y_{-}}>$Tuva $\check{c}$ -

${ }^{5}$ I cannot exclude the possibility of an assimilation in the case of Tuva words sildiis and sïstik. 
Old-Turkic $y \bar{a} z$ 'summer' (ED 982b) > Tuva čas 'vesna'.

b. Tuva yadara- 'bednet', niščit', stanovit'sja bednym, niščim, razorjat'sja' $\leftarrow$ Mongolian yadara- 'to be unable to try in vain; to be tired, exhausted; to succumb (with fatigue), break down (with fatigue); to be reduced to poverty; to need urgently' (*yada-rA- Intransitive Dev.V.).

In contrast, the Tuva verb yadara- preserves the Mongolian initial $y$-, showing that the word entered the Tuva language after the change of the initial $y$ - to $\check{c}-$ had ended.

4. Maybe the two different forms of the Mongolian word qajig $u$ 'side, flank, near' are not the results of two different borrowings. Nevertheless, for semantic reasons I discuss them as two different words.

a. $\quad$ Tuva word xayī 'raspoložennyj v storone ot čego-libo, nahodjaščijsja vdaleke; zaholustnyj' belongs to the earlier layer, because in some cases in the Tuva language the sound $\check{z}$ in an intervocalic position alternates with $y$. For example:

Tuva dažirgan dayïrgan 'taežnaja piščuha (Certhia)';

Tuva kažañ kayañ 'droblennaja krupa (iz žarennoj pšenicy ili jačmenja)';

Tuva čažig 'bryzgi': cf. čayïk 'liven'”;

b. I list the Tuva word $x a z ̌ \bar{i} \bar{i}$ 'storona, bok, bokovaja storona; nahodjaščijsja $\mathrm{v}$ storone' in the earlier layer too in accordance with the long vowel. In the Tuva language, the quality of the long vowel in the place of the juncture $V C V$ depends on the first vowel, whereas in Mongolian it depends on the second. ${ }^{6}$ The long $\bar{i}$ of Tuva words shows that the word entered the Tuva language before the development of the long vowel in Mongolian. For example:

The development of long vowels in the Tuva language $V^{l} C V^{2}>\bar{V}^{T}$ :

Old-Turkic ag̈̈̈r 'heavy' (ED 88b) > Tuva $\bar{a} r$ 'tjaželyj, dorogoj (o cene)';

Old-Turkic bag̈̈rr 'the liver' (ED 317a) > Tuva bār 'pečen'; pečenka (kuša$\left.n^{\prime} e\right)^{\prime}$;

Old-Turkic $o \dot{g} u l$ 'offspring, child; son' (ED 83b) > Tuva $\overline{o l}$ 'syn, mal'čik, paren’; detenyš; šahm. peška';

Old-Turkic yogiun 'thick' > Tuva čōn 'tolstyj; nizkij, gustoj (o golose)';

The development of long vowels in the Mongolian languages $V^{1} C V^{2}>\bar{V}^{2}$ :

Literary Mongolian ag ula 'mountain' > Khalkha $\bar{u} l$, Buryat $\bar{u} l a$, Oirat $\bar{u} l^{a}$;

Literary Mongolian egür 'nest; lair' > Khalkha, Buryat, Oirat $\bar{u} r$;

Literary Mongolian ebčigü $(n)$ 'sternum, chest; brisket' > Khalkha öwčū, Buryat $\ddot{u} b s \bar{u}$, Oirat öptsü.

The change of Mongolian $* V j V \rightarrow$ Tuva $V \check{z} V$ is a regular phenomenon of the Tuva language in the borrowings of Mongolian words. For example:

Tuva ažil 'rabota, trud' $\leftarrow$ Mongolian: Literary Mongolian ajul 'work, job, occupation, employment', Khalkha ajull, Buryat ažal;

Tuva bužar 'skvernyj, pozornyj, gnusnyj; razg. očen' horošo, otlično, zamečatel'no' $\leftarrow$ Mongolian: Literary Mongolian bujar 'dirt; abomination,

${ }^{6}$ For a detailed discussion on the long vowels in the Tuva language, see Khabtagaeva (2004). 
infamy; defiled; dirty, impure, dishonourable, disgraceful; obscene; extremely, very', Khalkha buzar, Buryat buzar, Oirat buzr;

Tuva kežege 'kosa (zapletennye volosy)' $\leftarrow$ Mongolian: Literary Mongolian gejige "nape of the neck; plait or braid of hair, pigtail, queue; hair in general', Khalkha gejeg, Buryat gezege, Oirat gidžig;

5. The Mongolian word tariyačin 'peasant, boor' is reflected as tarāăi and tarāči in the Tuva language.

a. $\quad$ The Tuva word tarāăi 'hleborob' shows the change of intervocalic $* V \check{V} V>$ $V \check{z} V$ which is a regular Tuva phenomenon and places the word in the earlier layer. For example:

Old-Turkic ačìg 'bitter; sour' (ED 21b) > Tuva ažig 'kislyj, gor'kij; gore, skorb";

Old-Turkic ičin 'inside, mutually' (ED 28a) > Tuva ižin 'život, želudok; vnutrennosti, nutro, soderžimoe čego-libo';

Tuva bižik 'pis'mennost'; cirkuljar, pis'mennoe ukazanie; pis'mo, poslanie, zapiska' $\leftarrow$ Mongolian: Literary Mongolian bičig 'anything written (as letters of the alphabet or characters); system of writing, script; inscription; written communication, letter, missive, memorandum, document, certificate' < biči- 'to write, inscribe', Khalkha, Oirat bičig, Buryat bešeg $\leftarrow$ Turkic: Old-Turkic bitig 'inscription, book, letter, document' < biti- 'to write' (ED 303a);

b. The Tuva form tarāčìn 'krest' janin, zeledelec, hleborob, zemlepašec', cf. tarā$\check{c} i$ ' tot, kotoryj jedet za hlebom; tot, kotoryj jedet chtoby dostat' hleba' preserves the Mongolian ${ }^{*} V \check{c} V$, that is why it belongs to the later layer. For example:

Tuva oñgača 'koloda (dlja korma skota)' $\leftarrow$ Oirat ongg்očo ongg்oča 'ship, boat; trough, trencher', Literary Mongolian ongyoča 'vessel, boat, ship; airplane; receptacle for water or fodder for livestock, trough', Khalkha ongoc(on), Buryat ongoso;

Tuva bačim 'spešnyj, toroplivyj, ekstrennyj; sumatošnyj, suetlivyj; peren. gorjačij, naprjažennyj, zatrudnitel'nyj; peren. dušnyj' $\leftarrow$ Khalkha, Oirat bačim, cf. Literary Mongolian bačim 'hasty, urgent, quick, instant; short (of time), urgently, quickly', Buryat bašam.

\section{Words that were borrowed despite the existence of an original Turkic word in the same meaning}

In these case, the original Turkic words were retained, too. For example: 'bear':

a. adig < Old-Turkic adïg (ED 45b);

b. xayïrakan $\leftarrow$ Mongolian: Literary Mongolian qayiraqan 'merciful, gracious; sacred mountain; a formula introducing or concluding a prayer; also 
used as an interj. of surprise, astonishment, indignation, etc.' $(<$ qayir-a 'love; grace, mercy, compassion' $+K A n$ diminutíve);

c. mažálay $\leftarrow$ Mongolian: Literary Mongolian majalai 'sivatagi medve, góbi medve' [Gobi bear] (Kara 243b), cf. Khalkha majálai, Oirat madžálá, Kalmuk madžál ${ }^{a}$;

'hare':

a. kodan < Old-Turkic qodan (ED 678a);

b. [bora] tólay $\leftarrow$ Mongolian: Literary Mongolian taulai, cf. Khalkha, Buryat tūlai, Oirat taulai tōlai toulai, Kalmuk túlä $(\leftarrow *$ tabǐš: Old-Turkic 'owl': taßǐs̆gan (ED 447a);

a. $\ddot{u} g \ddot{u}<$ Old-Turkic $\overline{\ddot{u} g i ́}$ (ED 101b);

b. mežergen $\leftarrow$ Mongolian: Literary Mongolian *bečergen < begčergen, $\mathrm{cf}$. Buryat begserge 'sova, syč';

'sand':

a. kum < Old-Turkic qum (ED 625b); 'vein':

b. elezin $\leftarrow$ Mongolian: Literary Mongolian elesün 'sand, dust';

a. damïr < Old-Turkic tamar tamïr 'vein, artery' (ED 508a);

b. sudal $\leftarrow$ Mongolian: Literary Mongolian sudal sudasun ( $<*^{*}$ sudalsun) 'vein, artery', cf. Khalkha sudal $\sim$ sudas, Buryat hudal hudahan, Oirat sudul $\sim$ sudal;

'silver':

a. xümǚ̌ < Old-Turkic kümǚs (ED 723b);

b. möñü̈n $\leftarrow$ Mongolian: Literary Mongolian mönggün 'silver, money'; 'axe':

a. baldi < Old-Turkic baltu (ED 333b);

b. süge $\leftarrow$ Mongolian: Literary Mongolian süke 'axe, hatchet'.

The question arises how to explain this phenomenon. In certain cases, tabooistic reasons might be suggested, as with animal names (bear, hare and owl) and international "culture-words" (vein, silver, axe). But the main reason for borrowing a Mongolian word, while the original Turkic word was also preserved, lies in intense bilinguism.

\section{Compound words}

The strength of bilinguism can also be observed in the following group of Tuva compound words, constructed from synonymous word pairs: one member of the compound is Turkic, while the other is Mongolian. For example:

'heavy; difficult' $\quad \bar{a}$-berge $\leftarrow$ Old-Turkic a ä̈rr 'heavy' (ED 88b) + Mongolian: Literary Mongolian berke 'difficult, hard; burdensome, troublesome; complicated, serious; difficulty, hardship; trouble'; 
'face' alïn-širay Ł Old-Turkic alïn 'forehead' (ED 147b) + Mongolian: Literary Mongolian čirai 'face, physiognomy; appearance, mien';

'bedding, mattress' döžek-širtek Ł Old-Turkic töšek 'mattress, bedding' (ED 563b) + Mongolian: Literary Mongolian širdeg 'saddlepad';

'heat, hot weather' izig-xalūn Ł Old-Turkic isig 'hot, heat' (ED 246a) + Mongolian: Literary Mongolian qalayun 'hot, warm; intimate; heat, warmth; fever', cf. Khalkha, Buryat, Oirat xalūn;

'life, existence' amï-tïn $\leftarrow$ Mongolian: Literary Mongolian ami 'life; breath, power of respiration' + Old-Turkic tïn 'breath' (ED 512a);

'work, job' ažil-iš $\leftarrow$ Mongolian: Literary Mongolian aǰil 'work, job, occupation, employment' + Old-Turkic ǐs 'work, labour' (ED 254a);

'taste' amdan-čimden $\leftarrow$ Mongolian: Literary Mongolian amtan 'taste'; cf. Old-Turkic ye- 'to eat' (ED 869b);

'journey; trip' ayan-čoruk $\leftarrow$ Mongolian: Literary Mongolian ayan 'travel, journey, expedition' + Old-Turkic yorïq 'movement' (ED 963a).

\section{Re-borrowings}

In the last group, I have collected Mongolian loanwords which are ultimately of Turkic origin, i.e. they are re-borrowings, but the original Turkic word was also retained. Thus, we find two words with the same meaning. For example:

'beestings, colostrum'

'just a little'

'war'

'young'

'nail, peg'

'ram'
Tuva $\underline{\bar{a} s}<$ Old-Turkic ag $u z \sim u \dot{g} u z$ 'biestings, colostrum, the first milk produced after parturition' (ED 98a) $\rightarrow$ Mongolian: $\mathrm{cf}$. Literary Mongolian uүuray 'colostrum, the first milk after delivery; beestings; the white of an egg', Khalkha, Buryat, Oirat $\bar{u}$ rag $\rightarrow$ Tuva $\bar{u}$ rak;

Tuva $\underline{a s}<$ Old-Turkic $\bar{a} z$ 'few, scanty, a little' (ED 277a) $\rightarrow$ Mongolian: cf. Literary Mongolian arai 'just a little too...; not quite...; hardly, scarcely, barely; with difficulty' $\rightarrow$ Tuva aray; Tuva $\underline{c} \bar{c} \underline{a}<$ Old-Turkic yagi 'enemy; hostile' (ED 898a) $\rightarrow$ Mongolian: cf. Literary Mongolian dayin 'war, battle; hostility, enmity' $\rightarrow$ Tuva daÿ̈n;

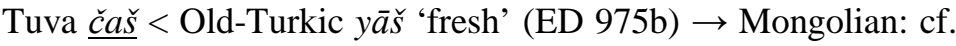
Literary Mongolian ǰalag̀u 'young, youthful; youth', Khalkha jalú, Buryat, Oirat zalū $\rightarrow$ Tuva čalī;

Tuva kadag (< kada- 'to bush, to stave' $-G$ Dev.N.) < Old-Turkic qadu- 'to sew or stitch very firmly' (ED 596b) $\rightarrow$ Mongolian: cf. Literary Mongolian qadayasun 'nail, peg, spike' (< qada- 'to drive in, knock in; to nail' -GAsUn Dev.N.) $\rightarrow$ Tuva kadāzïn; Tuva koškar (<*qočqar <*qoč) < Old-Turkic qoč qočñár 'ram' (ED 592a) $\rightarrow$ Mongolian: cf. Literary Mongolian quča 'ram; uncastrated lamb' $\rightarrow$ Tuva $\underline{k u} \underline{c} \underline{a}$; 
'power, might' Tuva $\underline{k u ̈ s ̌}<$ Old-Turkic kī̈̌ 'strength' (ED 693a) $\rightarrow$ Mongolian: cf. Literary Mongolian küčü 'power, force, strength; effort; energy; validity' $\rightarrow$ Tuva kü̈č̈

'marten, Siberian Tuva küzen < Old-Turkic küzän 'polecat' (ED 761b) $\rightarrow$ Mongopolecat' lian: cf. Literary Mongolian küren-e 'skunk, polecat' $\rightarrow$ Tuva

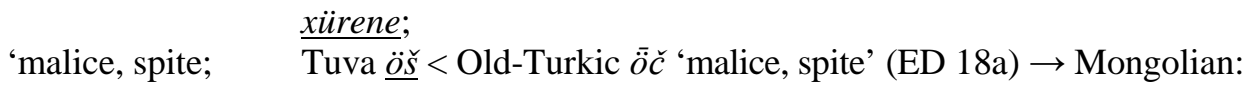
vengeance' cf. Literary Mongolian öšiye(n) 'animosity, hostility, hatred; vengeance, revenge', Oirat öšén, Khalkha öšö $(n)$, Buryat ühö $(n)$ $\rightarrow$ Tuva öžén;

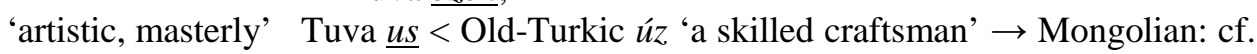
Literary Mongolian uran 'artist, craftsman; art, craft' $\rightarrow$ Tuva uran.

In this paper I have tried to present the special case of the Tuva language in which the presence of a vast number of Mongolian loanwords is not only due to a cultural impact, as in the case of other Turkic languages, but rather it can be ascribed to a state of bilinguism which persisted for centuries.

\section{Bibliography}

Baranova, Z. I.-Kotov, A. V. (2001): Bol'šoj russko-kitajskij slovar'. Moskva.

Buryat: see Čeremisov (1973)

Čeremisov, K. M. (1973): Burjatsko-russkij slovar'. Moskva.

Chinese: see Baranova-Kotov (2001)

Coloo, J̆. (1988): BNMAU dax' mongol xelnii nutgiin ayalguunï tol' bičig. Oird ayalguu [Dictionary of the dialects of Mongolia. The Oirat dialect]. Ulaanbaatar.

Kalmuk: see Ramstedt (1935)

Kara, Gy. (1998): Mongol-magyar szótár [Mongolian-Hungarian dictionary]. Budapest.

Khabtagaeva, B. (2004): A tuva nyelv mongol jövevényszavainak hosszú magánhangzói [The long vowels of the Mongolian loanwords in the Tuva language]. In: LingDok 3. Nyelvészdoktoranduszok dolgozatai. Szeged, pp. 101-110.

Khabtagaeva, B. (2005): Mongolic Loanwords of Turkic Origin in Tuvan. Turkic Languages 9, pp. 85-92.

Khalkha: see Kara (1998); Luwsandendew (1957)

Krueger, J. R. (1978): Materials for an Oirat-Mongolian to English Citation Dictionary. 1-3. Bloomington, Indiana.

Kuular, D. S. (1961): Bytovanija “Gesera” v Tuve. In: Učenye zapiski TNIIJaLI. Vypusk 9. Kyzyl.

Lessing, F. D. (1996): Mongolian-English Dictionary. Bloomington.

Literary Mongolian: see Lessing (1996)

Luwsandendew, A. (1957): Mongol-oros tol' [Mongolian-Russian dictionary]. Moskva.

Oirat: see Krueger (1978); Coloo (1988)

Pal'mbah, A. A. (1953): Russko-tuvinskij slovar'. Moskva.

Poppe, N. (1955): Introduction to Mongolian Comparative Studies. Helsinki.

Ramstedt, G. J. (1935): Kalmückisches Wörterbuch. Helsinki. 
Rassadin, V. I. (1980): Mongolo-burjatskie zaimstvovanija v sibirskih tjurkskih jazykah. Moskva, pp. $58-65$.

Samdan, A. (2000): Kratkoe opisanie sobranija mongol'skih rukopisej i ksilografov rukopisnogo fonda Instituta gumanitarnyh issledovanij Respubliki Tyva. In: Orientalistica Iuvenile. Sbornik rabot molodyh sotrudnikov i aspirantov. Moskva, Vol. I. pp. 128-133.

Sazykin, A. G. (1992): Sobranie mongol'skih rukopisej i ksilografov iz fondov Tuvinskogo respublikanskogo kraevedčeskogo muzeja imeni 60 bogatyrej (Kyzyl). In: Tjurkskie $i$ mongol'skie pamjatniki. Tekstologičeskie i kul'turologičeskie aspekty issledovanija. Moskva, pp. $45-58$.

Tatarincev, B. I. (1976): Mongol'skoe jazykovoe vlijanie na tuvinskuju leksiku. Kyzyl.

Tatarincev, B. I. (2000): Étimologičeskij slovar' tuvinskogo jazyka. Novosibirsk.

Tenišev, E. R. (1968): Tuvinsko-russkij slovar'. Moskva.

Tibetan: Sarat Chandra Das (2000): A Tibetan-English Dictionary. Delhi.

Tuva: see Pal'mbah (1953); Tenišev (1968)

Vladimircov, B. J. (1929): Sravnitel'naja grammatika mongol'skogo pis'mennogo jazyka i halhaskogo narečija. Leningrad. 